\title{
Resource Use Efficiency and Constraint Analysis of Summer Mungbean Cultivation in Rice-Wheat Cropping System
}

\author{
D.K. Bishnoi, D.P. Malik, Neeraj Pawar*, Nirmal Kumar and Sumit \\ Department of Agricultural Economics, CCS Haryana Agricultural University, Hisar, Haryana, India \\ *Corresponding author: npawar70@gmail.com (ORCID ID: 0000-0002-3040-0297)
}

Received: $10-09-2019$

Revised: $14-01-2020$

Accepted: 25-02-2020

\begin{abstract}
The study was conducted in eastern and western zones of Haryana in 2017-18. From eastern zone Kurukshetra and Panipat and from western zone Hisar district were selected on basis of acreage under summer mungbean. The outcomes of production function analysis reveal that there is scope for reorganization of resources used in cultivation of summer mungbean to optimize their use to enhance returns in the study area. In all the districts, the usage of resources which are showing negative production elasticity should be decreased to achieve the resource optimality and the use of resources viewing more than unity production elasticity should be encouraged to enhance the profitability condition. The analysis of constraints in cultivation of summer mungbean as opined by the sampled farmers recite that non-availability of suitable machine for harvesting, non-procurement of produce by Govt. agencies, harvest price less than MSP were recorded as the major constraints in the study area. Keeping in view the findings of the study, it is suggested that there is need to re-orient the usage of resources for attaining higher returns from summer mungbean cultivation, multiplication of short duration varieties seed, need to develop suitable and low cost harvesting machinery and procurement arrangement of produce at MSP.

\section{Highlights}

(0 There is need to develop suitable harvesting machinery and incentivise it for faster adoption and assured procurement of produce at MSP by the govt. agencies. There is need for adequate availability of seed of short duration varieties of 55-60 days like Virat (IPM25) and SML 668 for promotion in rice-wheat growing areas to suit best in existing space available in summer season.
\end{abstract}

Keywords: Resource Use Efficiency, Marginal Value Product, Marginal Factor Cost, Minimum Support Price, Return to scale, Elasticity of production, B:C Ratio

Pulses are important for nutritional security and for alleviating malnutrition among the poor masses in India. These are rich sources of energy, dietary fibre, protein, minerals and vitamins as required for human health. In addition, pulses also contain significant amounts of other essential nutrients like calcium, iron and lysine (Gowda et al. 2013). Recent research studies suggested that consumption of pulses may have potential health benefits by reduced risk of many chronic diseases like cardiovascular diseases, cancer, diabetes, osteoporosis, hypertension and gastrointestinal disorders (Jacobs and Gallaher, 2004). Mungbean requiring low input, short duration pulse crop fits very well in the rice-wheat cropping system during summer season in Haryana. After harvesting of wheat, fields remain vacant for 65-70 days till planting of succeeding crop i.e. rice. There is huge potential of cultivation short cultivars of pulses like mungbean by utilizing fallow land. No doubt cultivation of summer mungbean helps to generate additional farm income with short time span but also to overcome shortage of pulses, improve/

How to cite this article: Bishnoi, D.K., Malik, D.P., Pawar, N., Kumar, N. and Sumit (2020). Resource use efficiency and constraint analysis of summer mungbean cultivation in rice-wheat cropping system. Economic Affairs, 65(1): 117-122. 
maintain soil fertility and avoid early planting of rice for saving of irrigation water. Mungbean adds $33-37 \mathrm{~kg}$ of nitrogen $(\mathrm{N})$ to the soil after harvest and thus helps in saving of about 25 per cent nitrogen for the succeeding crop (Sekhon et al. 2007). The leading pulses states i.e.Madhya Pradesh, Maharashtra, Uttar Pradesh, Rajasthan and Andhra Pradesh contributed over 75 per cent of total pulses production in India. Madhya Pradesh is the highest pulse-producing state (3.2 million tonnes/annum) followed by Maharashtra and Uttar Pradesh. In terms of productivity, Haryana has the highest yield of $824 \mathrm{~kg} /$ ha followed by Madhya Pradesh, Uttar Pradesh and Bihar (Gowda et al. 2013). No doubt, the share of pulses to total foodgrain production in the country in terms of area and production has declined since with evolution of high viewing cultivars of food crops like wheat and paddy. The continuous decline in production level forced the country to import pulses of around 4-5 million annually to meet demand of vegetarian population. The higher price of pulses in domestic and international markets caused attention for enhancing production of pulses in the country in $12^{\text {th }}$ Plan by cultivating pulses in fallow areas, replacing less remunerative crops like coarse cereals, inclusion of pulse crop as catch crop in existing cropping systems as well as productivity enhancement through adoption of improved production technologies. Further, higher increase in MSP of pulses, procurement arrangement through government agencies and incentivization of pulses cultivators led to record production of 25.42 million tonnes of pulses in the country. However, still the productivity level of pulses $\left(853 \mathrm{~kg} \mathrm{ha}^{-1}\right)$ in India is far below than global average productivity (1023 $\mathrm{kg} \mathrm{ha}^{-1}$ ) due to low adoption of improved cultivars, cultivation of poor fertility, less use of nutrients etc (Anonymous, 2017-18).

In Haryana, the cropping pattern twisted towards rice and wheat due to profitability, amount of risk involved, procurement at MSP and expanded irrigated facilities. The area under pulses was 1150 thousand ha. at the time of formation of state in 1966 reduced to level 72.20 thousand ha in 2017-18 due to low profitability of pulse crops (Statistical Abstract of Haryana, 2017-18). The prevailing rice-wheat system in the state resulted into contamination and depletion of ground water, stagnation in yield level, deterioration of soil health, heavy occurrence of biotic stresses etc. has posed threat to sustainability of cultivation of crops in future. Keep in view; the inclusion of pulses in existing cropping systems in the state is only option at one hand for improving soil fertility and use of recommended doses of inputs and use of quality seed on other hand to improved productivity level of pulses. Therefore, the paper is attempted to analyse the extent of resources use and constraints in cultivation of summer mungbean in Haryana.

\section{MATERIALS AND METHODS}

The present study was confined to one district (Hisar) from western zone and two districts (Kurukshetra and Panipat) from eastern zone of the state on basis of acreage under summer mungbean. Form each identified district, 20 mungbean cultivators of three villages were selected randomly from the list of mungbean growers incentivized by State Department of Agriculture \& Farmers' Welfare and Krishi Vigyan Kendras of CCS Haryana Agricultural University. The relevant information pertaining to various resources like seed, farm machinery, human labour, irrigation, farm operation etc. were extracted from personal interaction with cultivators using well-structured interview schedule.

\section{Analytical tools}

Cobb-Douglas function was employed with four exogenous variables i.e. human labour $\left(X_{1}\right)$, machine labour $\left(X_{2}\right)$, seed $\left(X_{3}\right)$, irrigation $\left(X_{4}\right)$ in monetary term. The model adopted was as follows:

$$
\begin{aligned}
& \ln Y=\ln a+b_{1} \ln X_{1}+b_{2} \ln X_{2}+b_{3} \ln X_{3}+b_{4} \ln X_{4}+\ln \mu \\
& Y=\text { Returns (per hectare in } ₹ \text { ) } \\
& a=\text { Intercept } \\
& X_{1}=\text { Human labour } \\
& X_{2}=\text { Machine labour } \\
& X_{3}=\text { Seed } \\
& X_{4}=\text { Irrigation } \\
& b_{1} \text { to } b_{4}=\text { Respective elasticity co-efficients }
\end{aligned}
$$

Returns to scale (RTS) was calculated by summing production elasticities of all the inputs ( $\left.\sum b i\right)$. If, $\sum b i:=1, \sum b i:>1$ and $\sum b i:<1$ it indicates constant, increasing and decreasing returns to scale. 
Marginal value productivity (MVP) indicates the expected increase in gross returns forthcoming from the use of an additional unit of relevant input, while the level of other inputs remaining unchanged.

A resource or input factor is considered to be used most efficiently if its marginal value product (MVP) is just sufficient to offset its input marginal cost (IMC). Equality of MVP to factor cost is the basic condition that must be satisfied for resource use efficiently. If the ratio of MVP to IMC is less than one, it indicates that excess use of the particular resource is being used under the existing price conditions and vice versa. Resource-use efficiency is worked out by computing the difference of MVP to opportunity cost.

A list of all the important constraints in summer mungbean was prepared with help of literature, scientists of various departments of university, development officials, progressive farmers etc. Thus, a opinion of 60 respondents were recorded to elicit the major constraints in the cultivation of mungbean. The collected data were tabulated and analysed using Garrett ranking technique to interpret the obtained result.

\section{Garrett's Ranking Technique}

To find out the most significant factor which influences the respondent, Henry Garrett's (1969) ranking technique was used. As per this method, respondents have been asked to assign the rank for each constraints and the outcome of such ranking has been converted into score value with the help of the following formula:

$$
\text { Percent position }=\frac{100(R i j-0.3)}{N j}
$$

Where;

$$
\begin{aligned}
& R i j=\text { Rank given for the } \mathrm{i}^{\text {th }} \text { variable by } \mathrm{j}^{\text {th }} \\
& \text { respondents }
\end{aligned}
$$

$N j=$ Number of variable ranked by $j^{\text {th }}$ respondents

With the help of Garrett's table, the per cent position estimated is converted into scores. Then for each factor, the scores of each individual are added and then total value of scores and mean values of score is calculated. The factors having highest mean value is considered to be the most important factor. The final ranking of the factor in order to fix their relative priority was done on the basis of their mean score.

\section{RESULTS AND DISCUSSION}

The decision for use of a particular resource in cultivation of farm enterprise is very pertinent for attaining optimum yield with incurring least expenses on procurement of input. The wisdom of cultivator lies on level of use of resources, their purchase at reasonable price, timely application of resources and follow up recommended agronomic practices for realizing higher returns from cultivation of farm enterprise. The resource use analysis give an idea about usage of resources and needs to improve the use of particular resource for increasing returns from farm business.

Therefore, based on data collected from mungbean growers of three districts; Hisar, Kurukshetra and Panipat, Cobb Douglas production function was employed to determine the efficiency level of individual resource used. The resources like seed, human labour, machine labour and irrigation were identified as major contributing exogenous variables in cultivation of mungbean. The production function analysis fitted for resource use in study area districts reveals that the regression co-efficients of human labour and irrigation resources were positive and machine labour and seed were negative for Kurukshetra and Hisar districts (Table 1). Whereas in case of Panipat district, human labour and machine labour were positive while seed and irrigation were negative.

Table 1: Resource use efficiency of summer mungbean in Haryana

\begin{tabular}{lllllll}
\hline & \multicolumn{5}{c}{ Kurukshetra district } \\
\cline { 2 - 6 } Particulars & GM & Bi & MVP & MFC & r \\
\hline Constant & 1093616 & & & & \\
Human labour & 2365.37 & $0.36^{* *}$ & 2.88 & 1 & 2.88 \\
Machine labour & 3467.77 & $-0.65^{* *}$ & -3.51 & 1 & -3.51 \\
Seed cost (Kg) & 996.70 & -0.24 & -4.46 & 1 & -4.46 \\
Irrigation & 832.12 & $0.04^{* *}$ & 0.09 & 1 & 0.09 \\
R-square value : & 0.479 & & & & \\
\hline
\end{tabular}

\begin{tabular}{|c|c|c|c|}
\hline \multirow{2}{*}{ Particulars } & \multicolumn{3}{|c|}{ Panipat district } \\
\hline & GM & $\mathbf{B i}$ & MVP MFC \\
\hline
\end{tabular}

$\mathrm{RTS}=\sum \mathrm{bi}=-0.52=$ Decreasing return to scale, (Overutilization of resources) 


\begin{tabular}{llllll} 
Human labour & 2425.32 & $0.29^{* *}$ & 1.99 & 1 & 1.99 \\
Machine labour & 2703.99 & $0.16^{* *}$ & 0.97 & 1 & 0.97 \\
Seed cost $(\mathrm{Kg})$ & 880.27 & -0.06 & -1.23 & 1 & -1.23 \\
Irrigation & 912.99 & -0.005 & -0.09 & 1 & -0.09 \\
R- square value & 0.94 & & & & \\
\hline
\end{tabular}

$\mathrm{RTS}=\sum \mathrm{bi}=0.38=$ Decreasing return to scale, $($ Overutilization of resources)

\begin{tabular}{lllllll}
\hline \multirow{2}{*}{ Particulars } & \multicolumn{3}{l}{ Hisar district } & & \\
\cline { 2 - 6 } & GM & Bi & MVP & MFC & r \\
\hline Constant & 1339759 & & & & \\
Human labour & 2246.31 & $0.02^{* *}$ & 0.16 & 1 & 0.16 \\
Machine labour & 2097.30 & -0.35 & -2.65 & 1 & -2.65 \\
Seed cost (Kg) & 647.40 & -0.34 & -8.39 & 1 & -8.39 \\
Irrigation & 1212.71 & $0.03^{* *}$ & 0.42 & 1 & 0.42 \\
R- square value & 0.68 & & & & \\
\hline
\end{tabular}

$\mathrm{RTS}=\sum \mathrm{bi}=-0.63=$ Decreasing return to scale, $($ Overutilization of resources)

In Kurukshetra and Hisar districts, human labour and irrigation coefficients were found to be statistically significant at 5 per cent level. While in case of Panipat district, human labour and machine labour were found to be statistically significant at 5 per cent level. This implied that every five per cent increase in human labour and irrigation would increase gross return by 0.36 and 0.04 per cent for Kurukshetra, 0.02 and 0.03 per cent for Hisar, respectively. While in case of Panipat human labour and machine labour would increase gross return by 0.29 and 0.16 per cent, respectively. Whereas all other resource coefficients were non-significant indicating that expenditure on these inputs were of not much influence on total returns attained from cultivation of mungbean .The summation of regression coefficients worked out for Kurtukshetra, Panipat and Hisar districts to be $-0.52,0.38$ and -0.63 , respectively indicates decreasing returns to scale. The estimated co-efficient of multiple determinations $\left(R^{2}\right)$ revealed that selected inputs (human labour, machine labour, seed cost and irrigation) were capable of explaining 47.90, 94.70 and 68.20 per cent variation in summer mungbean production in Kurukshetra, Panipat and Hisar districts, respectively.

The human labour for Kurukshetra (2.88) and Panipat (1.99) were greater than unity. It indicates that the human labour was underutilized in both the districts. Hence, there is needed to be increase the use of inputs to attain optimum level of output. On the other side, the ratios of MVP to MFC were less than unity for machine labour, seed and irrigation for Kurukshetra, Panipat and Hisar districts. It reflects that all the inputs were over utilized and use of these inputs needs to be curtailed to higher returns. There was ample scope for exploitation the use of these resources to maximize the production and to increase the gross returns. It is imperative from the study that use of underutilized resources in the cultivation of mungnean resulted into higher yield while reduce the use of over utilized inputs caused in reduction of expenses incurred. This ultimately stemmed into higher profitability from cultivation of mungbean. Similar results were obtained by Saikumar et al. (2013) in their study.

\section{Constraints faced in cultivation of summer mungbean}

Although mungbean cultivation in study area is getting momentum with sincere effort of development officials and research scientists but still mungbean cultivation is facing several hindrance for attaining potential yield and large area coverage. The constraint analysis of mungbean cultivation was done using theGarrett's ranking technique for 60 sampled farms and on basis of scores, the rank of particular constraint was decided. The feedback of mungbean cultivators in study area indicates that non-availability of suitable harvesting machine was most important constraint due to shortage and higher wages of labour as well as delay in timely harvesting of crop and timely planting of succeeding crop.

The constraints as ranked on basis of information extracted form mungbean cultivators in order of priority were non-procurement of produce by Govt. agencies, harvest price less than Minimum Support Price (MSP), shortage of labour for harvesting operation, inadequate availability of quality seed.

The other hindrances noticed in interaction of mungbean cultivators at field level were, lack of market information, inferior quality of seed purchased from different sources, non-availability of seed of short duration varieties, stray animals, poor demand of produce in market, synchronous maturity etc. of crop at rank fourth, fifth, sixth, seventh, eighth, ninth, tenth and eleventh with total score $659,513,464,447,439,420,373$ and 
Table 2: Constraints faced by the mungbean growers in Haryana

\begin{tabular}{|c|c|c|c|c|c|c|c|c|c|}
\hline \multirow{2}{*}{$\begin{array}{l}\text { S1. } \\
\text { No. }\end{array}$} & \multirow[t]{2}{*}{ Particulars } & \multicolumn{2}{|c|}{ Panipat } & \multicolumn{2}{|c|}{ Kurukshetra } & \multicolumn{2}{|l|}{ Hisar } & \multicolumn{2}{|c|}{ Overall } \\
\hline & & $\begin{array}{l}\text { Total } \\
\text { score }\end{array}$ & Rank & $\begin{array}{l}\text { Total } \\
\text { score }\end{array}$ & Rank & $\begin{array}{l}\text { Total } \\
\text { score }\end{array}$ & Rank & $\begin{array}{l}\text { Total } \\
\text { score }\end{array}$ & Rank \\
\hline 1 & $\begin{array}{l}\text { Non-availability of suitable machine for } \\
\text { threshing }\end{array}$ & 264 & 1 & 264 & 1 & 262 & 1 & 790 & 1 \\
\hline 2 & $\begin{array}{l}\text { Non-purchase of produce by Govt. } \\
\text { agencies }\end{array}$ & 242 & 2 & 242 & 2 & 244 & 2 & 728 & 2 \\
\hline 3 & Harvest price is less than MSP & 222 & 3 & 150 & 6 & 218 & 4 & 662 & 3 \\
\hline 4 & $\begin{array}{l}\text { Non-availability of labour for harvesting } \\
\text { of crop }\end{array}$ & 220 & 4 & 220 & 3 & 219 & 3 & 659 & 4 \\
\hline 5 & Non-availability of quality seed & 170 & 5 & 170 & 4 & 173 & 5 & 513 & 5 \\
\hline 6 & Lack of market information. & 154 & 6 & 154 & 5 & 156 & 6 & 464 & 6 \\
\hline 7 & $\begin{array}{l}\text { Quality of seed purchased from } \\
\text { different sources }\end{array}$ & 150 & 7 & 96 & 11 & 147 & 8 & 447 & 7 \\
\hline 8 & $\begin{array}{l}\text { Non-availability of seed of short } \\
\text { duration varieties }\end{array}$ & 148 & 8 & 148 & 7 & 143 & 9 & 439 & 8 \\
\hline 9 & Problem of stray animals & 136 & 9 & 136 & 8 & 148 & 7 & 420 & 9 \\
\hline 10 & Demand of produce in market & 126 & 10 & 126 & 9 & 121 & 10 & 373 & 10 \\
\hline 11 & Synchronous maturity of crop & 98 & 11 & 98 & 10 & 102 & 11 & 298 & 11 \\
\hline 12 & High cost of seed & 80 & 12 & 80 & 12 & 79 & 12 & 239 & 12 \\
\hline 13 & Shortage of irrigation water & 53 & 13 & 53 & 13 & 50 & 13 & 156 & 13 \\
\hline 14 & $\begin{array}{l}\text { Cultivation of mungbean delays the } \\
\text { sowing of next crop }\end{array}$ & 34 & 14 & 34 & 14 & 35 & 14 & 103 & 14 \\
\hline
\end{tabular}

298 respectively. High cost of seed, shortage of irrigation water and cultivation of mungbean delay the sowing of next crop ranked twelfth, thirteen and fourteen in study area $\mathrm{s}$ and overall basis with a total score 239, 156, and 103, respectively (Table 2). Similar outcome were obtained by Bhatia, (1991) and Grover, et al. (2005) in their respective study.

\section{CONCLUSIONS AND POLICY IMPLICATIONS}

The results of production function analysis unveils that there is scope for reorganisation of resources to optimise their use to enhance returns in the study area. In all the districts, the use of resources which are showing negative production elasticity should be decreased to achieve the optimality in the resource use and the use of resources showing more than unity production elasticity should be encouraged to enhance the profitability condition. The analysis of constraints encountered by the sampled farmers in reveals that non-availability of suitable machine for threshing, non-procurement of produce by Govt. agencies, less remunerative price were found the foremost constraints in the study area. Keeping in view, the findings of the study, it is suggested that cultivation of summer mungbean cultivation and efficient utilization of resources should be encouraged. There is need to develop suitable harvesting machinery and incentivise it for faster adoption and procurement arrangement of produce at MSP by the govt. agencies. There is urgent need for multiplication of seed of short duration varieties of 55-60 days like Virat (IPM25) and SML 668 for promotion in rice-wheat growing areas to suit best inexisting space available in summer season.

\section{REFERENCES}

Anonymous, 2017-18. Ministry of agriculture \& Farmers Welfare (Department of Agriculture, Cooperation \& Farmers Welfare).

Bhatia, M.S. 1991. Economic constraints in increasing pulse production. Agriculture Situation in India, 46(9): 279-284.

Garrett, E.H. and Woodworth, R.S. 1969. Statistics in psychology and education. Vakils, Feffer and Simons Pvt. Ltd., Bombay: 329.

Gowda, C.L.L., Srinivasan, S., Gaur, P.M. and Saxena, K.B. 2013. Enhancing the productivity and production of pulses in India. In: Shetty P K, Ayyappan S and Swaminathan M 
$\underset{A E S S R A}{\sqrt{W}}$

Bishnoi et al.

S (eds.) Climate Change and Sustainable Food Security, pp. 63-76. National Institute of Advanced Studies, Bangalore and Indian Council of Agricultural Research, New Delhi.

Grover, D.K., Weinberger, K., Shanmugasundaram, S. and Singh, G. 2005.Constraint analysis of Mungbean production in cereal-based cropping system in Punjab. Journal of Research Punjab Agricultural University, 42(2): 223-231.

Jacobs, D.R. and Gallaher, D.D. 2004. Whole grain intake and cardiovascular disease: A review. Current Atheroscler, 6: 415-23.
Saikumar, C. Bharamappanavara, Mundinamani, S.M., Naik B.K. and Kiresur, V.R. 2013. Resource Use Efficiency and Constraints in Farming in the Tank Commands: The Case of North Eastern Karnataka. Journal of Rural Development, 32(3): 311-320.

Sekhon, H.S., Bains, T.S., Kooner, B.S. and Sharma, P. 2007. Grow summer mungbean for improving crop sustainability, farm income and malnutrition. Acta Horticulturae, 752: 459-64.

Statistical Abstract of Haryana, 2017-18. 